\title{
List of Most Significant Publications of Waclaw Szybalski*
}

Professor Wacław Szybalski's most significant scientific achievements are listed below in twenty-three points. He has authored over five hundred publications in the fields of chemistry, microbiology, molecular and synthetic biology, genetics, mutagenesis, and genetic engineering. Many of Professor Szybalski's discoveries resulted from him first developing a series of original research techniques that then gave rise to new fields of science and novel concepts such as synthetic biology, gene therapy, and multiple drug therapy. The Web of Science, the most important database of scientific publications, lists 265 publications by Professor Szybalski that have been cited by other scientists over 12,000 times; his Hirsh index is 56 , showing the strong impact of his work on science.

\section{1.}

PAPER CHROMATOGRAPHY (Lwów and Końskie) KINETICS OF IODINE-AZIDE REACTIONS (Copenhagen) (1941-1949)

Paper chromatography was the first novel technique introduced by Professor Szybalski at the start of the Second World War. It served as a substitute for traditional aluminum oxide $\left(\mathrm{AlO}_{3}\right)$ chromatography, because of reagent shortages during the war. Work on this began in Lwów, but it was finished at the Agricultural Laboratory in Końskie in 1944-1945. If not for the war, the publication of this technique could have brought the Professor much renown, because a team of scientists from England was awarded the Nobel Prize in 1952 for independently developing and applying the same technique.

Szybalski W., Oznaczanie aminokwasów przy pomocy dwuwymiarowej chromatografii na bibule [Determination of amino acids with two-dimensional chromatography on paper]. Przemyst Chemiczny, 1950, Vol. 5, pp. 32-37.

Professor Szybalski began his research on the mechanisms and kinetics of chemical reactions, and more specifically the reaction of iodine with azide catalyzed by carbon disulphide, during his stay in Denmark with Dr. Niels Hofman-Bang, as proposed to him by Professor Jens Christiansen, a pioneer in the kinetics of chain reactions. The result of this work was proving that the iodine-azide reaction is a five-step reaction, and not, as it was previously described, a three-step reaction.

Hofman-Bang N., Szybalski W., The iodine-azide reaction. II. The catalytic effect of carbon disulphide. Acta Chemica Scandinavica 1949, Vol. 3, pp. 1418-1429.

Szybalski W., Kinetyka i mechanizm reakcji chemicznych [Kinetics and mechanisms of chemical reactions]. Wiadomości Chemiczne, 1950, Vol. 4, pp. 193-213.

*(C)Copyright by the Professor Waclaw Szybalski Foundation, ISBN 978-83-8206-015-7

Preprint by the permission of Professor Wacław Szybalski Foundation and Gdańsk University Press

\author{
2. \\ MICROBIAL CORROSION OF IRON PIPES \\ (Copenhagen) \\ MUSTY PSEUDOMONAS \\ (Gdańsk and Copenhagen) \\ (1946-1949)
}

Professor Szybalski's first scientific achievement that brought him notoriety outside of academic circles was his research on the corrosion of the water pipes in Copenhagen. He was successful in replicating the microbiological and electrochemical mechanism of the corrosive reaction caused by the Leptothrix ochracea iron bacteria, under laboratory conditions, and to develop a simple, yet effective, method of preventing it.

Olsen E., Szybalski W., Aerobic microbiological corrosion of water pipes. Acta Chemica Scandinavica, 1949, Vol. 3, pp. 1094-1116.

Mansa J.L., Szybalski W., Corrosion due to tuberculation in water systems. Acta Chemica Scandinavica, 1950, Vol. 4, pp. 1275-1299 (see also: Corrosion 1950, Vol. 8, pp. 381-390).

Szybalski W., Korozja punktowa w roztworach wodnych [Point corrosion in aqueous solutions]. Przemyst Chemiczny, 1951, Vol. 7, pp. 88-93.

Professor Szybalski began his research on the microflora of musty eggs in 1948 in Gdańsk, together with Stanisław Grabiec and Władysław Tuszyński, and their results were published in the journal of the Institute of Maritime and Tropical Medicine. Szybalski continued his study on the subject in Copenhagen where he classified a newly discovered bacterial strain. He compared it to bacteria described in Bergey's Manual of Determinative Bacteriology and the American Type Culture Collection, and named it Pseudomonas perolens var. Gdańsk, in honor of Gdańsk, Poland.

Szybalski W., A comparative study of bacteria causing mustiness in eggs. Nature, 1950, Vol. 165, pp. 733-734.

\section{GENETICS OF ANTIBIOTIC RESISTANCE GRADIENT PLATE TECHNIQUE} (1950-1963)

Shortly after arriving at the laboratory in Cold Spring Harbor in the United States, Professor Szybalski developed his gradient plate technique, which helped him form the basis for the genetics of bacterial resistance to antibiotics. The gradient plate technique, used to this day in many laboratories around the world, was described in Professor Szybalski's first paper published in Science.

This quick method of detecting even minute differences in the antibiotic resistance of bacterial strains enabled the Professor to isolate multiple mutants resistant to specific drugs, and to initiate a genetic study of the mechanism of resistance, including cross resistance and collateral sensitivity of several types of bacteria (Escheri- 
chia coli, Streptococcus aureus, Mycobacterium sp. and Bacillus sp.).

Szybalski W., Gradient plate technique for study of bacterial resistance. Science, 1952, Vol. 116, pp. 46-48.

Szybalski W., Bryson V., Genetic studies on microbial cross-resistance to toxic agents. III. Cross-resistance of Mycobacterium ranae to twenty-eight antimycobacterial agents. American Review of Tuberculosis, 1954, Vol. 69, pp. 267-279.

Bryson V., Szybalski W., Microbial Drug Resistance. Advances in Genetics, 1955, Vol. 7, pp. 1-46.

\section{4.}

\section{MULTIPLE DRUG THERAPY}

\section{(1952-1957)}

Professor Szybalski's quantitative study of the development of resistance to two or more antibiotics allowed him to formulate the principles of rational multiple drug therapy, which later proved to be very successful in treating illnesses such as tuberculosis, leukemia in children, and AIDS.

Due to its great importance in practical use, multidrug therapy, promoted by the Professor as a way of preventing the development of genetic resistance to antibiotics, was even written about in the news media (see, e.g., New York Times, 18.09.1952, p. 31).

Grace E.J., Bryson V., Szybalski W., Demerec M., Potential danger of isoniazid resistance through failure to use multiple chemotherapy in treatment of tuberculosis. Journal of the American Medical Association, 1952, Vol. 149, pp. 1241.

Szybalski W., Bryson V., One-step resistance development to isoniazid and sodium-p-aminosalicylate. Journal of Bacteriology, 1953, Vol. 66, pp. 468-469.

Szybalski W., Theoretical basis of multiple chemotherapy. Tuberculology, 1956, Vol. 15, pp. 82-85.

\section{5.}

\section{GENETICS OF STREPTOMYCES}

(1955-1959)

Professor Szybalski published a series of pioneering works on the genetics of the antibiotic-producing actinobacteria, Streptomyces. He was one of the first scientists to demonstrate genetic exchange in these bacteria and organized the first ever International Conference on the Genetics of Streptomyces and other antibiotic-producing microorganisms, which was convened in New York in 1959.

Braendle D.H., Szybalski W., Genetic interaction among Streptomycetes: heterokaryosis and synkaryosis. Proceedings of the National Academy of Sciences of the United States of America, 1957, Vol. 43, pp. 947-955.

Braendle D.H., Gardiner B., Szybalski W., Heterokaryotic compatibility of Streptomyces. Journal of General Microbiology, 1959, Vol. 20, pp. 442-450.

Szybalski W. [ed.], Genetics of Streptomyces and other Antibiotic-Producing Microorganisms, Annals of the New York Academy of Sciences, 1959, Vol. 81.

\section{6. \\ IN VITRO SYNTHESIS OF FUNCTIONAL TRANSFORMING DNA} (1961-1964)

Professor Szybalski and Dr. Rose Litman were the first to demonstrate that enzymatically synthesized DNA (the synthesis was made using DNA polymerase isolated from E. coli bacteria cells by Dr. Litman) is biologically active, because it is able to transfect bacterial cells. This was the first documented instance of "synthesizing life" in a test tube. At the time, the hypothesis that synthetic DNA could be introduced into a living cell and that it could be proven that synthetic DNA then carried out its genetic function bordered on science fiction.

The remarkable importance and almost revolutionary nature of the experiment is further asserted in a statement made by John Cairns, the world-class biochemist and director of CSHL, who, in his summary of the 32nd Cold Spring Harbor Symposium (1963), said that biology should be divided into the periods before and after the Litman \& Szybalski experiment.

Once again, Professor Szybalski became the focus of the news media, which featured his picture and a description of this experiment and academic achievements (see, e.g., New York Times, September 21, 1952, p. E11) nearly simultaneously with descriptions of multiple drug therapy.

Litman R.M., Szybalski W., Enzymatic synthesis of transforming $D N A$, Biochemical and Biophysical Research Communications 1963, Vol. 10, pp. 473-481.

\section{7. \\ TRANSFECTION OF HUMAN CELLS GENE THERAPY}

(1962-1969)

Alongside his revolutionary experiment of synthesizing life in a test tube, Professor Szybalski continued to contribute to the world of science by proving that DNA can be introduced into human cells (not only into bacterial cells) and that the introduced DNA is also genetically active. It was yet another of the Professor's discoveries that was worthy of a Nobel Prize. For his study of human cell transfection, Professor Szybalski chose the Detroit 98 (D98) cell line, originally derived from bone marrow. His research resulted in academic achievements in five categories, which also correspond to the individual stages of the study:

Isolating many new cell line mutants and accurately determining their mutation rates. Additionally, methods for maintaining human cell lines under laboratory conditions and precisely measuring their growth were improved.

Szybalski W., Smith M.J., Genetics of human cell lines. I. 8-Azaguanine resistance, a selective single-step marker. Proceedings of the Society of Experimental Biology and Medicine, 1959, Vol. 101, pp. 662-666.

Szybalski W., Genetics of human cell lines. II. Method for determination of mutation rates to drug resistance. Experimental Cell Research, 1959, Vol. 18, pp. 588-591.

(2) Demonstrating that the mutants of the Detroit 98 cell line, resistant to 8-azahipoxanthin, lost the gene responsible for coding HPRT proteins, or hypoxanthine phosphoribosyl transferase. The lack of this enzyme causes Lesch-Nyhan syndrome. The HPRT enzyme was then known under its former name IMPPase; using the abbreviation HPRT caused many misunderstandings in 1960-1990; it was not until the 1990s that the abbreviations HPRT or HGPRT came into general use.

Szybalski W., Szybalski E.H., Brockman R.W., Biochemical basis of sequential mutations toward resistance to purine analog in human cell lines. Proceedings of the American Association for Cancer Research, 1961, Vol. 27, pp. $2-3$.

(3) Developing an innovative method of eukaryotic cell selection on HAT medium (named for its ingredients: hypoxanthine, aminopterin, and thymidine), which Professor Szybalski, along with his wife Elizabeth, was able to create with his knowledge of the biosynthetic pathways of purines. HAT is an especially valuable medium for allowing the selection of even extremely infrequently occurring cells containing the HPRT enzyme from mutants that lack this enzyme (see point 2 ). 
Szybalski W., Szybalski E.H., Ragni G., Genetic studies with human cell lines. National Cancer Institute Monograph, 1962, Vol. 7, pp. 75-89.

The HAT medium continues to be widely used to this day. It should be noted that it allows for the selection of cellular hybrids essential for the production of monoclonal antibodies. Georges Köhler and César Milstein were awarded the Nobel Prize in 1984 for developing the method of producing monoclonal bodies.

(4) Proving scientifically that it is possible to successfully transfect human cells. Professor Szybalski and his wife Elizabeth's experiment consisted of inserting DNA isolated from wild-type $\mathrm{HPRT}^{+}$cells into HPRTcells and then successfully growing them on HAT medium. HPRT cells are unable to grow on HAT medium, as they are unable to utilize hypoxanthine as the only source for the biosynthesis of purines.

Szybalski E.H., Szybalski W., Genetics of human cell lines. IV. DNA-mediated heritable transformation of a biochemical trait. Proceedings of the National Academy of Sciences of the United States of America. 1962, Vol. 48, pp. 2026-2034.

(5) The experiments listed above showed that that it was possible to utilize the transformation or transfection of human cells to correct genetic defects on a cellular level. This was, therefore, the beginning of a new field of science that Professor Szybalski called gene therapy. This idea would not become the subject of interest for geneticists, biologists, or doctors until many years later, but the Professor propagated its potential and used this name during his lectures (including at the International Biochemical Congress in Moscow) from as early as 1961, when nobody yet appreciated the importance of the experiments he was performing. It would be at least a decade before any other similar work or genetic-biochemical evidence for the viability of gene therapy would exist.

Professor Szybalski developed the first selective systems for the isolation and study of mutants and revertants of the same gene, and for measuring the mutation rates related to the loss and acquisition of the gene responsible for regulating the biosynthesis of a specific enzyme in human cell lines.

Szybalski W., Szybalski E.H., Selective systems for measuring forward and reverse mutation rates involving loss and gain of enzyme in human cell lines [in:] $V$ International Congress of Biochemistry. Abstracts and Communications. Moscow, 10-16 August 1961. Oxford: Pergamon Press Ltd. - Warszawa: Państwowe Wydawnictwo Naukowe 1961, p. 411.

Szybalski W., Use of the HPRT gene and the HAT selection technique in DNA-mediated transformation of mammalian cells: First steps toward developing hybridoma techniques and gene therapy. BioEssays. 1992, Vol. 14, pp. 495-500.

The history and the various uses of HAT selection and gene therapy are described in part in a special edition of Gene (Volume 525) issued on the occasion of the celebrations of the 50th anniversary of gene therapy in 2012, which took place at the Jagiellonian University and the Polish Academy of Arts and Sciences in Kraków, which also organized the conference "Fifty Years of Gene Therapy. Wacław Szybalski's Contributions to Science and Humanity."

Szybalski W., The 50th anniversary of gene therapy: Beginnings and present realities. Gene, 2013, Vol. 525, pp. 151-154.

Dulak J., Uchto J., Jozkowicz A., 50 years of gene therapy. A contribution of Wacław Szybalski to science and humanity. Gene, 2013, Vol. 525, pp. 149-150.
Bigda J.J., Koszałka P., Wacław Szybalski’s contribution to immunotherapy: HGPRT mutations \& HAT selection as first steps to gene therapy and hybrid techniques in mammalian cells. Gene, 2013, Vol. 525, pp. 158-161.

Lojkowska E., Kosiedowski S., Waclaw Szybalski: Lwow, Gdansk, Madison - Life of a scientist and philanthropist. Gene, 2013, Vol. 525, pp. 155-157.

Professor Szybalski's experiments on human cell lines also indicated that the replication of human DNA is semi-conservative.

Djordjevic B., Szybalski W., Genetics of human cell lines. III. Incorporation of 5-bromo-, and 5-iododeoxyuridine into the deoxyribonucleic acid of human cells and its effect on radiation sensitivity. Journal of Experimental Medicine, 1960, Vol. 112, pp. 509-531.

\section{MUTAGENESIS AND CARCINOGENESIS (1958-1968)}

Many of Professor Szybalski's research projects focused on the very important issue in genetics that is mutagenesis (mutations in DNA). In order to understand the mechanism of mutation and the effectiveness of mutation-causing factors (mutagens), Szybalski developed a method for testing the sensitivity of bacteria to chemical mutagens. The so-called spot test, a method of testing on agar plates, either directly or using paper discs, allowed him to quickly and easily determine the mutagenicity of many chemical compounds. He tested over 400 compounds, stating that about $5 \%$ of them are effective mutagens. The described method contributed to the development of the Ames test in the 1970s.

Iyer V.N., Szybalski W., Two simple methods for the detection of chemical mutagens. Applied Microbiology, 1958, Vol. 6, pp. 23-29.

Szybalski W., Observations on chemical mutagenesis in microorganisms. Annals of the New York Academy of Sciences. 1958, Vol. 76, pp. 475-489.

Professor Szybalski also investigated the mechanism of mutagenesis in bacteria, spheroplasts, and human cells.

Iyer V.N., Szybalski W., The mechanisms of chemical mutagenesis. I. Kinetic studies on the action of triethylene melamine (TEM) and azaserine. Proceedings of the National Academy of Sciences of the United States of America, 1958, Vol. 44, pp. 446-456.

Steinman I.D., Iyer V.N., Szybalski W., The mechanism of chemical mutagenesis. II. Interaction of selected compounds with manganous chloride. Archives of Biochemistry and Biophysics, 1958, Vol. 76, pp. 78-86.

Iyer V.N., Szybalski W., Mutagenic effect of azaserine in relation to azaserine resistance in Escherichia coli. Science, 1959, Vol. 129, pp. 839-840.

Szybalski W., The mechanism of chemical mutagenesis with special reference to triethylene melamine action [in:] Developments in Industrial Microbiology, ed. B.M. Miller, New York: Plenum Press 1960, pp. 231-241.

Lorkiewicz Z., Szybalski W., Genetic effects of halogenated thymidine analogs incorporated during thymidylate synthetase inhibition. Biochemical and Biophysical Research Communications, 1960, Vol. 2, pp. 413-418.

Lorkiewicz Z., Szybalski W., Mechanism of chemical mutagenesis. IV. Reaction between triethylene melamine and nucleic acid components. Journal of Bacteriology, 1961, Vol. 82, pp. 195-201.

Szybalski W., Pitzurra M., The mechanism of chemical mutagenesis. III. Induced mutations in spheroplasts of Escherichia coli. Journal of Bacteriology, 1959, Vol. 77, pp. 621-622. 
Szybalski W., Smith M.J., Effect of ultraviolet light on mutation to 8-azaguanine resistance in a human cell line. Federation Proceedings, 1959, Vol. 18, pp. 336.

Szybalski W., Ragni G., Cohn N.K., Mutagenic response of human somatic cell lines [in:] Cytogenetics of Cells in Culture, ed. R.J.C. Harris, Symposia of the International Society for Cell Biology, Vol. 3, Academic Press 1964, pp. 209-221.

An important discovery made by Professor Szybalski was indicating that mitomycin $C$ and porfiromycina class of antibiotics that interact with DNA and are able to crosslink complementary DNA chains in vivo. He described the chemistry of mitomycin activation as the chemical reduction of mitomycin, while the DNA crosslinking mechanism was described as activated by carbonium ions.

Iyer V.H., Szybalski W., A molecular mechanism of mitomycin action: linking of complementary DNA strands. Proceedings of the National Academy of Sciences of the United States of America, 1963, Vol. 50, pp. 355-362.

Iyer V.N., Szybalski W., Mitomycins and porfiromycin: chemical mechanism of activation and crosslinking of DNA. Science, 1963, Vol. 145, pp. 55-58.

Szybalski W., Iyer V.N., Crosslinking of DNA by enzymatically or chemically activated mitomycins and porfiromycins, bifunctionally alkylating antibiotics. Federation Proceedings, 1964, Vol. 23, pp. 946-957.

Szybalski W., Structural modifications of DNA: crosslinking, circularization and single-strand interruptions. Abhandlungen der Deutschen Akademie der Wissenschaften, Klasse für Medizin 1964, Bd. 4, pp. 1-19.

Another important achievement of Professor Szybalski's was indicating the causative relationship between mutagenesis and carcinogenesis. Before his discovery, many scientists thought that the reason behind the development of cancer cells was changes occurring in proteins. However, Szybalski's experiments indicated that carcinogenesis occurs in DNA and is caused by specific mutations in a DNA sequence. The work of Professor Szybalski's doctoral student revealed that the known carcinogens, 2-acetylaminofluorene and N-methyl-4-aminoazobenzene, interact chemically with DNA and cause mutations in specific genes, which, in turn, leads to the process of neoplasia.

Maher Sr. V.M., Miller E.C., Miller J.A., Szybalski W., Mutations and decreases in density of transforming DNA produced by derivatives of the carcinogens 2-acetylaminofluorene and N-methyl-4-aminoazobenzene. Molecular Pharmacology. 1968, Vol. 4, pp. 411-426.

Professor Szybalski also studied mutagenesis in human cellsSzybalski W., Smith M.J., Effect of ultraviolet light on mutation to 8-azaguanine resistance in a human cell line. Federation Proceedings, 1959, Vol. 18, p. 336.

\section{RADIOSENSITIZATION OF DNA AND CAN- CER RADIOTHERAPY}

(1958-1965)

While studying the interactions between radiation and thymidine analogues, Professor Szybalski discovered that the introduction of 5-bromo- and 5-iododeoxyuridine into the DNA of bacterial and human cells increases their sensitivity to ultraviolet (UV) light and X-rays (X), which results in the death of cells containing such modified DNA. The discovery of DNA radiosensitization allowed for a breakthrough in cancer radiotherapy that sparked the interest of Professor Henry Kaplan, a then famous radiologist from California, and of several professors of oncology and radiology in Madison.
However, the studies carried out simultaneously in California and Wisconsin did not provide the anticipated clinical results, because enzymes produced by the liver cleaved bromine and iodine atoms from the haloanalogs, which proved to be toxic for the patients. As a result, it was impossible to permanently incorporate haloanalogs into the DNA. Nevertheless, the phenomenon of DNA radiosensitization has found many other non-clinical applications. It constitutes, among other things, the best proof that DNA is the main receptor of radiation, and this was useful in demonstrating for the first time that retrovirus RNA replication occurs through DNA synthesis. Howard Temin, Professor Szybalski's friend, was awarded the Nobel Prize for this discovery.

Djordjevic B., Szybalski W., Genetics of human cell lines. III. Incorporation of 5-bromo-, and 5-iododeoxyuridine into the deoxyribonucleic acid of human cells and its effect on radiation sensitivity. Journal of Experimental Medicine, 1960, Vol. 112, pp. 509-531.

Erikson R.L., Szybalski W., Molecular radiobiology of human cell lines. I. Comparative sensitivity to X-rays and ultraviolet light of cells containing halogen-substituted DNA. Biochemical and Biophysical Research Communications, 1961, Vol. 4, pp. 258-261.

Ragni G., Szybalski W., Molecular radiobiology of human cell lines. II. Effects of thymidine replacement by halogenated analogues on cell inactivation by decay of incorporated radiophosphorus. Journal of Molecular Biology, 1962, Vol. 4, pp. 338-346.

Erikson R.L., Szybalski W., Molecular radiobiology of human cell lines. III. Radiation sensitizing properties of 5-iododeoxyuridine. Cancer Research, 1963, Vol. 23, pp. 122-130.

Erikson R.L., Szybalski W., Molecular radiobiology of human cell lines. V. Comparative radiosensitizing properties of 5-halodeoxycytidines and 5-halo-deoxyuridines. Radiation Research, 1963, Vol. 20, pp. 252-262.

Szybalski W., Properties and applications of halogenated deoxyribonucleic acids [in:] The Molecular Basis of $\mathrm{Ne}$ oplasia (A Collection of Papers Presented at the Fifteenth Annual Symposium on Fundamental Cancer Research, 1961), Austin: University of Texas Press 1963, pp. 147-171.

Kozinski A.W., Szybalski W., Dispersive transfer of the parental DNA molecule to the progeny of phage øX-174. Virology, 1959, Vol. 9, pp. 260-274.

Szybalski W., Opara-Kubinska Z., DNA as principal determinant of cell radiosensitivity. Radiation Research, 1961, Vol. 14, pp. 508-509.

Opara-Kubinska Z., Lorkiewicz Z., Szybalski W., Genetic transformation studies. II. Radiation sensitivity of halogen-labeled DNA. Biochemical and Biophysical Research Communications, 1961, Vol. 4, pp. 288-291.

Szybalski W., Lorkiewicz Z., On the nature of the principal target of lethal and mutagenic radiation effects [in:] Strableninduzierte Mutagenese - Erwin-Baur-Gedächtnisvorlesungen II, hrsg. von H. Stubbe, Abhandlungen der Deutschen Akademie der Wissenschaften, Klasse für Medizin 1962, Bd. 1, pp. 63-71.

Opara-Kubinska Z., Borowska Z., Szybalski W., Genetic transformation studies. III. Effect of UV light on the molecular properties of normal and halogenated DNA. Biochimica et Biophysica Acta, 1963, Vol. 72, pp. 298-309.

\section{0.}

\section{TRANSCRIPTIONAL GENOMIC MAPPING} (1961-1980)

The construction of detailed DNA transcription maps became possible due to the method of preparative separation of two complementary DNA strands developed by Professor Szybalski. 
(1) The method of preparative separation consists of centrifugation of DNA in specially prepared solutions (most often in a solution of cesium chloride or sulphate and the poly(UG) polymer) in which individual DNA fractions are separated depending on the concentration gradient of the cesium compounds.

Szybalski W., Sampling of virus particles and macromolecules sedimented in an equilibrium density gradient Experientia, 1960, Vol. 16, p. 164.

Opara-Kubinska Z., Kubinski H., Szybalski W., Interaction between denatured DNA, polyribonucleotides, and ribosomal RNA: Attempts at preparative separation of the complementary DNA strands. Proceedings of the National Academy of Sciences of the United States of America, 1964, Vol. 52, pp. 923-930.

Lozeron H.A., Szybalski W., Suppression of RNA precipitation during $\mathrm{Cs}_{2} \mathrm{SO}_{4}$ density gradient centrifugation. Biochemical and Biophysical Research Communications, 1966, Vol. 23, pp. 612-618.

Szybalski W., Szybalski E.H., Equilibrium density gradient centrifugation [in:] Procedures in Nucleic Acid Research, Vol. 2, ed. G.L. Cantoni, D.R. Davies, New York: Harper and Row 1971, pp. 311-354.

Using his method of cesium chloride density gradient centrifugation of DNA, Professor Szybalski discovered a new type of DNA called satellite DNA.

Szybalski W., Mysterious satellites. Nature, 1970, Vol. 226, pp. 89-90.

(2) The use of the preparative DNA separation method in studying the bacteriophages T7 and lambda $(\lambda)$ proved that both strands of phage $\lambda$ DNA participate in the transcription process (RNA synthesis on a DNA template). This overturned the then prevalent idea that DNA contains sense and antisense strands and that only one DNA strand is transcribed by RNA polymerase.

Sheldrick P., Szybalski W., Distribution of pyrimidine clusters between the complementary DNA strands of certain Bacillus bacteriophages. Journal of Molecular Biology, 1967, Vol. 29, pp. 217-228.

Hradecna Z., Szybalski W., Fractionation of the complementary strands of coliphage $\lambda$ DNA based on the asymmetric distribution of the poly IG-binding sites. $V i$ rology, 1967, Vol. 32, pp. 633-643.

Summers W.C., Szybalski W., Totally asymmetric transcription of coliphage T7 in vivo: Correlation with poly $G$ binding sites. Virology, 1968, Vol. 34, pp. 9-16.

These works also resulted in the creation of the principle of a "transcriptional cascade" based on observations that the transcription of a specific gene complex may lead to a cascade of transcriptions of other gene complexes.

Taylor K., Hradecna Z., Szybalski W., Asymmetric distribution of the transcribing regions on the complementary strands of the coli phage $\lambda$ DNA. Proceedings of the National Academy of Sciences of the United States of America, 1967, Vol. 57, pp. 1618-1625.

(3) Proving that both DNA strands can take part in the transcription of DNA was instrumental in determining the orientation of genes and operons, and significantly sped up the process of mapping DNA transcription. Many detailed transcription maps were created as a result of identifying transcriptionally active regions by fragmenting DNA and deletion mutations of phage $\lambda$ DNA, and determining the transcription orientation by the hybridization of the separated DNA strands.

Szybalski W., Bøvre K., Fiandt M., Guha A., Hradecna Z., Kumar S., Lozeron H.A., Maher V.M., Sr., Nijkamp H.J.J., Summers W.C., Taylor K., Transcriptional controls in developing bacteriophages. Journal of Cellular Physiology, 1969, Vol. 74, suppl. 1, pp. 33-70.

Kumar S., Bøvre K., Guha A., Hradecna Z., Maher V.M., Sr., Szybalski W., Orientation and control of transcription in E. coli phage $\lambda$. Nature, 1969, Vol. 221, pp. $823-825$.

Nijkamp H.J.J., Bøvre K., Szybalski W., Controls of rightward transcription in coliphage $\lambda$. Journal of Molecular Biology, 1970, Vol. 54, pp. 599-604.

\section{1.}

\section{HETERODUPLEX GENOMIC MAPPING} (1968-1980)

Further progress in DNA mapping became possible thanks to the development of a technique created by Professor Szybalski (in cooperation with the laboratory of Dr. H. Ris) that utilized an electron microscope to map heteroduplexes (DNA molecules created by the hybridization of complementary strands from different phage lambda mutants). The first images obtained with this technique revealed the genomes of phages, the existence of which until then could only be inferred on the basis of genetic crosses. This technique allowed for measuring both single-strand and double-strand heteroduplex regions.

Westmoreland B.C., Szybalski W., Ris H., Mapping of deletions and substitutions in heteroduplex DNA molecules of bacteriophage lambda by electron microscopy. Science, 1969, Vol. 163, pp. 1343-1348.

In its day, this method was the most precise one for physically mapping deletions, insertions, and substitutions, and for the study of the correlations between genetic and physical maps of the phage lambda genome and other genomes.

Hradecna Z., Szybalski W., Electron micrographic maps of deletions and substitutions in the genomes of transducing coliphages $\lambda \mathrm{dg}$ and $\lambda$ bio. Virology, 1969, Vol. 38, pp. 473-477.

Lozeron H.A., Szybalski W., Congruent transcriptional controls and heterology of base sequences in coliphage $\lambda$ and ø80. Virology, 1969, Vol. 39, pp. 373-388.

Fiandt M., Hradecna Z., Lozeron H.A., Szybalski W., Electron micrographic mapping of deletions, insertions, inversions, and homologies in the DNAs of coliphages lambda and phi80 [in:] The Bacteriophage Lambda, ed. A.D. Hershey, Cold Spring Harbor: Cold Spring Harbor Laboratories 1971, pp. 329-354.

Wilgus G.S., Mural R.J., Friedman D.I., Fiandt M., Szybalski W., $\lambda$ imm434: a phage with a hybrid immunity region. Virology, 1973, Vol. 56, pp. 46-53.

\section{2. TRANSPOSABLE IS ELEMENTS (1972-1980)}

The use of heteroduplexes for the analysis of insertion sequences (IS) (DNA fragments that change their location within the genome; some are also called transposons or jumping genes) permitted discerning that these elements occur in almost every type of DNA and classifying them into five categories: IS1, IS2, IS3, IS4 and IS5.

Fiandt M., Szybalski W., Malamy M.H., Polar mutations in lac, gal, and phage $\lambda$ consist of a few IS-DNA sequences inserted with either orientation. Molecular \& General Genetics, 1972, Vol. 119, pp. 223-231.

Szybalski W., IS elements in Escherichia coli, plasmids and bacteriophages [in:] DNA Insertion Elements, Plasmids and Episomes, ed. A.I. Bukhari, J.S. Shapiro, S.L. Adhya, Cold Spring Harbor: Cold Spring Harbor Laboratory 1977, pp. 583-590. 


\section{3. \\ SYNTHETIC BIOLOGY \\ (1974-2009)}

Professor Szybalski's pioneering discoveries in the study of the genetics of the bacteriophage lambda $(\lambda)$, which included synthesizing biologically active DNA in a test tube and isolating and describing specific restriction enzymes and ligases, paved the way for research on other viruses and formed the basis for a new scientific discipline called synthetic biology. Professor Szybalski coined this term in 1974, describing his vision of moving forward from the descriptive phase of molecular biology to the phase of synthetic biology, in which new genomes and new synthetic organisms would be created.

Szybalski W., In Vivo and in vitro Initiation of Transcription [in:] Control of Gene Expression, ed. A. Kohn, A. Shatkay, New York: Plenum Press 1974, pp. 23-24, 404-405, 411-412, 415-417.

Szybalski W., Skalka A., Nobel-prizes and restriction enzymes. Gene, 1978, Vol. 4, pp. 181-182.

Szybalski W., Construction of novel regulatory circuits. 14th International Congress of Biochemistry, Prague, Czechoslovakia, July 10-15, 1988. Abstracts, Vol. TU: S13-4 (July 12, 1988), Videopress IOJ 16200 Prague 6, p. 22.

Szybalski W., History of synthetic biology: Witnessing molecular biology from its beginnings. Proceedings of The Fourth International Meeting on Synthetic Biology (SB 4.0), Hong Kong University of Science and Technology, The BioBrick Foundation, Oct. 10-12, 2008, pp. 48-50.

There have been several international conferences on synthetic biology to date (beginning with SB 1.0 in 2004, to SB 6.0 in 2013, and SB 7.0, which was held in Singapore in June 2017). Some of the most significant achievements in this field of science include the synthesis of the complete genome of the polio virus and the creation of the partially synthetic Mycoplasma bacteria.

14.

\section{MOLECULAR GENETICS OF PHAGE LAMB-} DA $(\lambda)$

(1969-2009)

The concept of synthetic biology has been formulated based on extensive research on the molecular genetics of the bacteriophage lambda $(\lambda)$, which has become a model virus in genetic research. Because of the vast scope of his studies and significant results, Professor Szybalski has often been jokingly called the father of lambdology. His pioneering discoveries were made in the following research topics:

(1) Research on the transcription of both DNA strands within the $\mathrm{b} 2$ region showed that both strands are transcribed and that the transcription can be either convergent or overlapping.

Bøvre K., Szybalski W., Patterns of convergent and overlapping transcription within the b2 region of coliphage $\lambda$. Virology, 1969, Vol. 38, pp. 614-626.

(2) The study of transcription control methods demonstrated the effectiveness of RNAi biosynthesis (encoded in plasmids and created through convergent transcription) in mammalian cells (unpublished work: Szybalski E., Kubinski H., Opara-Kubinska Z., Szybalski W.). Antisense mRNA, however, had little effect on transcription.

Hasan N., Somasekhar G., Szybalski W., Antisense RNA does not significantly affect expression of the galK gene of Escherichia coli or the $\mathrm{N}$ gene of coliphage lambda. Gene, 1988, Vol. 72, pp. 247-252.
(3) The locations of various promoters and operators for several prokaryotic operons were determined by physically mapping transcription-controlling elements.

Szybalski W., Genetic and molecular map of Escherichia coli bacteriophage lambda ( $\lambda$ ) [in:] Handbook of Biochemistry and Molecular Biology, Vol. 2, ed. G.D. Fasman, 3rd ed., Cleveland: CRC Press 1976, pp. 677-685.

Szybalski E.H., Szybalski W., A comprehensive molecular map of bacteriophage lambda. Gene, 1979, Vol. 7, pp. $217-270$.

Daniels D.L., Schroeder J.L., Szybalski W., Sanger F., Blattner F.R., A molecular map of coliphage lambda [in:] Genetic Maps, Vol. 3, ed. S.J. O’Brien, Cold Spring Harbor: Cold Spring Harbor Laboratory 1984, pp. 1-21.

(4) Research on the transcription of bacterial genes after being inserted into the phage lambda genome resulted in, among other things, determining the orientation of the gal, trp, lacI, and lacZYA operons, the gene responsible for coding tRNA, and the genes responsible for coding ribosomal RNA.

Guha A., Tabaczynski M., Szybalski W., The orientation of transcription for the galactose operon as determined by hybridization of gal mRNA with the separated DNA strands of coliphage $\lambda$ dg. Journal of Molecular Biology, 1968, Vol. 35, pp. 207-213.

Kumar S., Szybalski W., The orientation of transcription of the lac operon and its repressor gene $\mathrm{i}$ in Escherichia coli. Journal of Molecular Biology, 1969, Vol. 40, pp. 145-151.

Lozeron H.A., Szybalski W., Landy A., Abelson J., Smith J.D., Orientation of transcription for the amber suppressor gene $\mathrm{su}_{\mathrm{III}}$ as determined by hybridization between tyrosine tRNA and the separated strands of transducing coliphage $ø 80 \mathrm{dsu}_{\mathrm{III}}$. Journal of Molecular Biology, 1969, Vol. 39, pp. 239-243.

Miller, Jr., R.C., Besmer P., Khorana H.G., Fiandt M., Szybalski W., Studies on polynucleotides, XCVII. Opposing orientations and location of the $\mathrm{su}_{\text {III }}^{+}$gene in the transducing coliphages $\varnothing 80 \mathrm{psu}^{+}{ }_{\mathrm{III}}$ and $\varnothing 80 \mathrm{dsu}^{+}{ }_{\mathrm{III}} \mathrm{Su}_{\mathrm{III}}^{-}$ Journal of Molecular Biology, 1971, Vol. 56, pp. 363-368.

Fiandt M., Szybalski W., Blattner F.R., Jaskunas S.R., Lindahl L., Nomura M., Organization of ribosomal protein genes in Escherichia coli. I. Physical structure of DNA from transducing $\lambda$ phages carrying genes from the aroE-str region. Journal of Molecular Biology, 1976, Vol. 106, pp. 817-835.

Professor Szybalski also described the first example of a divergent bacterial operon (bio) that is transcribed from both DNA strands (bio $A$ leftward and bioB-F rightward transcription), and he created a complete map of the Escherichia coli bio operon.

Guha A., Saturen Y., Szybalski W., Divergent orientation of transcription from the biotin locus. Journal of Molecular Biology, 1971, Vol. 56, pp. 53-62.

Kotval J., Campbell A., Konopa G., Szybalski W., Leftward transcription in Escherichia coli bio operon does not require products of the rightward transcript. Gene, 1982, Vol. 17, pp. 219-222 [Erratum: Vol. 18, p. 366].

Szybalski E.H., Szybalski W., A physical map of the Escherichia coli bio operon. Gene, 1982, Vol. 19, p. 93.

(5) While studying the mechanism of transcription in prokaryotic organisms in vivo and in vitro, Szybalski's laboratory was the first to sequence DNA regions downstream from the major promoters. The key finding was that the promoter is not transcribed and that the first 5 'nucleotide of synthesized RNA is exactly the same in vivo (inside the living body) and in vitro (under laboratory conditions). 
Blattner F.R., Dahlberg J.E., Boettiger J.K., Fiandt M., Szybalski W., Distance from a promoter mutation to an RNA synthesis startpoint on bacteriophage $\lambda$ DNA. $N a$ ture New Biology, 1972, Vol. 237, pp. 232-236.

Dahlberg J.E., Lozeron H.A., Szybalski W., Identity of in vivo and in vitro initiation of four phage lambda RNAs. Bacteriophage Meeting, Cold Spring Harbor 1972, p. 86.

Szybalski W., In vivo and in vitro initiation of transcription [in:] Control of Gene Expression, ed. A. Kohn, A. Shatkay, New York: Plenum Press 1974, pp. 23-24, 404-405, 411-412, 415, 417.

(6) Based on his research on two mutually co-controlled short transcriptional regions of the lambda phage, lit, and oop, Professor Szybalski developed a hypothesis for the existence of introns (non-coding parts of the genome sequence) in 1974. This hypothesis was years ahead of the introduction of terms such as intron and exon in DNA research.

Hayes S., Szybalski W., Control of short leftward transcripts from the immunity and ori regions in induced coliphage lambda. Molecular \& General Genetics, 1973, Vol. 126, pp. 275-290.

Szybalski W., Transcription and replication in E. coli bacteriophage lambda [in:] Uptake of Informative Molecules by Living Cells, ed. L. Ledoux, Amsterdam: North-Holland Publ. Co. 1972, pp. 59-82.

Blattner F.R., Dahlberg J.E., Boettiger J.K., Fiandt M., Szybalski W., Distance from a promoter mutation to an RNA synthesis startpoint on bacteriophage $\lambda$ DNA. $N a$ ture: New Biology, 1972, Vol. 237, pp. 232-236.

(7) In collaboration with Dr. S. Adhya, Professor Szybalski determined the origin and the bidirectional nature of bacteriophage lambda DNA replication.

Stevens W.F., Adhya S., Szybalski W., Origin and bidirectional orientation of DNA replication in coliphage lambda [in:] The Bacteriophage Lambda, ed. A.D. Hershey, Cold Spring Harbor: Cold Spring Harbor Laboratory 1971, pp. 515-533.

\section{5. \\ TRANSCRIPTION TERMINATION} (1978-1990)

Professor Szybalski devoted much attention to the subject of the termination and anti-termination of the transcription process.

(1) Among the numerous terminators (sequences that mark the end of transcription) identified and cloned in Professor Szybalski's laboratory, many have found broad application in a variety of genetic constructs.

Luk K.-C., Szybalski W., Transcription termination: sequence and function of the rho-independent $t_{L 3}$ terminator in the major leftward operon of bacteriophage lambda. Gene, 1982, Vol. 17, pp. 247-258.

Luk K.-C., Dobrzanski P., Szybalski W., Cloning and characterization of the termination site $t_{\mathrm{I}}$ for the gene int transcript in coliphage lambda. Gene, 1982, Vol. 17, pp. 259-262.

Luk K.-C., Szybalski W., Characterization of the cloned terminators $t_{R 1}, t_{L 3}$ and $t_{I}$, and of the nutR antitermination site of coliphage lambda. Gene, 1982, Vol. 20, pp. 127-134.

Luk K.-C., Szybalski W., The $t_{\mathrm{L} 2}$ cluster of transcription termination sites between genes bet and ral of coliphage lambda. Virology, 1983, Vol. 125, pp. 403-418.

Luk K.-C., Szybalski W., A cluster of leftward, rho-dependent $\mathrm{t}_{\mathrm{J}}$ terminators in the $\mathrm{J}$ gene of coliphage lambda. Gene, 1983, Vol. 21, pp. 175-191.

Luk K.-C., Szybalski W., Tandem transcription-termination sites in the late rightward operon of bacterio- phage lambda. Molecular \& General Genetics, 1983, Vol. 189, pp. 289-297.

(2) Intensive research on the transcription termination process led to the discovery of the nut $\mathrm{L}$ and $n u t \mathrm{R}$ anti-termination elements.

Salstrom J.S., Szybalski W., Coliphage nutL-: a unique class of mutants defective in the site of gene $\mathrm{N}$ product utilization for antitermination of leftward transcription. Journal of Molecular Biology, 1978, Vol. 124, pp. 195-221.

While researching $\mathrm{N}$-dependent anti-termination in bacteriophage lambda, many of the variants of the nut sequence were synthesized chemically. At the time, these were the first examples of chemically synthesized DNA components responsible for controlling transcription. Anti-termination in some synthetic nut mutants was temperature sensitive, indicating that either proteins or RNA are involved in the anti-termination complex.

Salstrom, J.S., Fiandt, M., Szybalski, W., N-independent leftward transcription in coliphage lambda: deletions, insertions and new promoters bypassing termination functions. Molecular and General Genetics, 1979, Vol. 168, pp. 211-230.

Salstrom J.S., Fiandt M., Szybalski W., The site controlling the specificity of $\mathrm{N}$ action is outside the promoter-operator: a triple hybrid phage N21imm434nin5. Gene, 1979, Vol. 5, pp. 305-327.

Drahos D., Szybalski W., Antitermination and termination functions of the cloned nutL, $\mathrm{N}$, and $\mathrm{t}_{\mathrm{L} 1}$ modules of coliphage lambda, Gene, 1981, Vol. 16, pp. 261-274 [Erratum: Vol. 17 (1982), pp. 354-355].

Szybalski W., Drahos D., Luk K.-C., Somasekhar G., Modules for termination and antitermination of transcription in coliphage lambda [in:] Microbiology, ed. D. Schlessinger, Washington: American Society for Microbiology 1983, pp. 35-38.

Drahos D., Galluppi G.R., Caruthers M., Szybalski W., Synthesis of the nutL DNA segments and analysis of antitermination and termination functions in coliphage lambda. Gene, 1982, Vol. 18, pp. 343-354.

Peltz S.W., Brown A.L., Hasan N., Podhajska A.J., Szybalski W., Thermosensitivity of a DNA recognition site: activity of a truncated nutL antiterminator of coliphage lambda. Science, 1985, Vol. 228, pp. 91-93.

Hasan N., Szybalski W., Boundaries of the nutL antiterminator of coliphage lambda and effects of mutations in the spacer region between boxA and boxB. Gene, 1986, Vol. 50, pp. 87-96.

Hasan N., Szybalski W., Effect of the promoter structure on the transcription antitermination function. Gene, 1986, Vol. 50, pp. 97-100.

Szybalski W., Brown A.L., Hasan N., Podhajska A.J., Somasekhar G., Modular structure of the nut and qut antiterminators of transcription. Interactions between control elements of phage lambda and construction of novel regulatory circuits [in:] RNA Polymerase and the Regulation of Transcription, ed. W.S. Reznikoff, R.R. Burgess, J.E. Dahlberg, C.A. Gross, M.T. Record, M.P. Wickens, New York: Elsevier 1987, pp. 381-392.

(3) Apart from studying N-dependent anti-termination, Professor Szybalski's laboratory also researched the other phage lambda anti-termination system $-Q /$ $q u t$. Precise deletions in the qut sequence using the IIS BspMI restriction enzyme permitted the determination of the boundaries of the qut sequence and proved that the direct repeat sequences in the qut region have a significant impact on the effectiveness of anti-termination.

Somasekhar G., Szybalski W., Mapping of the Qutilization site (qut) required for antitermination of late 
transcription in bacteriophage lambda. Gene, 1983, Vol. 26, pp. 291-294.

Szybalski W., Drahos D., Luk K.-C., Somasekhar G., Antitermination: the lambda system. Modules for termination and antitermination of transcription in coliphage lambda [in:] Microbiology, ed. D. Schlessinger, Washington: American Society of Microbiology 1983, pp. 35-38.

Somasekhar G., Szybalski W., The functional boundaries of Q-utilization site required for antitermination of late transcription in bacteriophage $\lambda$. Virology, 1987, Vol. 158, pp. 414-426.

Kur J., Hradecna Z., Hasan N., Szybalski W., Evaluation of the multistep method for generating BspMI-mediated deletions in studies on the role of the direct 10$\mathrm{bp}$ repeat in the qut-controlled antitermination in phage lambda. Virology, 1989, Vol. 176, pp. 629-632.

Kur J., Hradecna Z., Hasan N., Szybalski W., The role of the direct repeat in qut-controlled antitermination in phage $\lambda$. Virology, 1990, Vol. 176, pp. 629-632.

16.

\section{RESTRICTION ENGINEERING}

(1980-1996)

Another area in which Professor Szybalski's achievements are widely recognized is the modification of the specificity of restriction enzymes, the aim of which was to enable cutting DNA strands at any chosen location. The results of this research were the development of the so-called universal restriction enzyme, and then of the "Achilles' heel" method.

(1) Studies on the conversion of class IIS restriction enzymes to universal endonucleases were performed for the FokI enzyme, which recognizes a specific sequence of 5'-AUGCC and cleaves the DNA at a distance of 9 and 13 nucleotides from the recognized sequence. Such a conversion required using a special oligonucleotide adapter to obtain DNA cleavage at a site complementary to the single-stranded domain of the specific adapter.

Szybalski W., Universal restriction endonucleases: designing novel cleavage specificities by combining adapter oligo-deoxynucleotide and enzyme moieties. Gene, 1985, Vol. 40, pp. 169-173.

Podhajska A., Szybalski W., Conversion of the FokI endonuclease to a universal restriction enzyme: cleavage of phage M13mp7 DNA at predetermined sites. Gene, 1985, Vol. 40, pp. 175-181.

Kim S.C., Podhajska A.J., Szybalski W., Cleaving DNA at any predetermined site with adapter-primers and class-IIS restriction enzymes. Science, 1988, Vol. 200, pp. 504-506.

Szybalski W., Kim S.C., Hasan N., Podhajska A.J., Class-IIS restriction enzymes - a review. Gene, 1991, Vol. 100, pp. 13-26.

Podhajska A.J., Kim S.C., Szybalski W., Conferring new specificities on restriction enzymes: cleavage at any predetermined site by combining an adapter oligodeoxynucleotide and a class-IIS enzyme. Methods in Ensymology, 1992, Vol. 216, Part G, pp. 303-309.

Kim S.C., Skowron P.M., Szybalski W., Structural requirements for the FokI-DNA interaction and oligonucleotide-instructed cleavage. Journal of Molecular Biology, 1996, Vol. 258, pp. 638-649.

This novel method of DNA cleavage with a universal restriction enzyme was patented.

Szybalski W., Universal restriction endonuclease, U.S. Patent No. 4, 935, 357 (June 19, 1990), pp. 1-14.

(2) The Achilles' heel cleavage method was received with great interest. It allowed for the selection of the cleavage site by covering it with a protein (or another compound; the first idea was a lactose repressor) and deactivating other sites by DNA methylation with methyltransferases. In the experimental phase, the use of the third strand of the oligonucleotide and the RecA protein was found to be the most effective in protecting DNA from methylation. This method (called RecA-AC) could be used for mapping and further genomic engineering.

Koob M., Grimes E., Szybalski W., Conferring operator specificity on restriction endonucleases. Science, 1988, Vol. 241, pp. 1084-1086.

Koob M., Szybalski W., Cleaving yeast and Escherichia coli genomes at a single site. Science, 1990, Vol. 250, pp. 271-273.

Szybalski W., Modifying specificities of restriction enzymes [in:] Biotechnology: Bridging Research and Applications, ed. D. Kamely, A.M. Chakrabarty, S.E. Kornguth (Proceedings of the U.S.-Israel Research Conference on Advances in Applied Biotechnology, June 24-30, 1990, Haifa, Israel), Boston: Kluwer Academic Publishers 1992, pp. 371-376.

Koob M., Burkiewicz A., Kur J., Szybalski W., RecAAC single-site cleavage of plasmids and chromosomes at any predetermined restriction site. Nucleic Acids Research, 1992, Vol. 20, pp. 5831-5836.

Szybalski W., RecA-mediated Achilles' heel cleavage. Current Opinion in Biotechnology, 1987, Vol. 8, pp. 75-81.

(3) Novel DNA cleaving and engineering methods, based on the unique properties of IIS restriction endonucleases.

Hasan N., Kim S.C., Podhajska A.J., Szybalski W., A novel multistep method for generating precise unidirectional deletions using BspMI, a class-IIS restriction enzyme. Gene, 1986, Vol. 50, pp. 55-62.

Pósfai G., Szybalski W., A simple method for locating methylated bases in DNA as applied to detect asymmetric methylation by M·FokIA. Gene, 1988, Vol. 69, pp. 147-151.

Pósfai G., Szybalski W., Increasing the FokI cleavage specificity from 5 to 7 base pairs by two-step methylation. Nucleic Acids Research, 1988, Vol. 16, p. 6245.

Pósfai G., Szybalski W., A simple method for locating methylated bases in DNA using class-IIs restriction enzymes. Gene, 1988, Vol. 74, pp. 179-191.

Kim S.C., Szybalski W., Amplification of cloned DNA as tandem multimers using BspMI-generated asymmetric cohesive ends. Gene, 1988, Vol. 71, pp. 1-8.

Kim S.C., Pósfai G., Szybalski W., A novel gene-fusing vector: construction of a 5'-GGmCC-specific chimeric methyltransferase M·BspRI/M·BsuRI. Gene, 1991, Vol. 100, pp. 45-50.

(4) Professor Szybalski was also actively involved in the codification of a uniform nomenclature for restriction and modifying enzymes.

Szybalski W., Blumenthal R.M., Brooks J.E., Hattman S., Raleigh E.A., Nomenclature for bacterial genes coding for class-II restriction endonucleases and DNA modification methyltransferases, Gene, 1988, Vol. 74, pp. 279-280.

Bestor H., Bhagwat S., Blumenthal M., Brooks E., Marinus M.G., Raleigh E.A., Szybalski W. [ed., Preface], Proceedings to the Third New England Biolabs Workshop on Biological DNA Modification. Papers Presented at Third New England Biolabs Workshop on Biological DNA Modification. Gene, 1995, Vol. 157, p. XI, 1-341.

Roberts R.J., Belfort M., Bestor Vol. et al., A nomenclature for restriction enzymes, DNA methyltransferases, homing endonucleases and their genes. Nucleic Acids Research, 2003, Vol. 31, pp. 1805-1812. 


\section{7. \\ EXPRESSION VECTORS WITH INVERTIBLE ELEMENTS NOVEL REGULATORY CIRCUITS (1984-1999)}

Professor Szybalski introduced an innovative method for regulating the activity of transcription promoters, by incorporating them between reversible elements.

(1) The first vector constructed was a plasmid that acted on demand by inversion. In the OFF orientation, the promoter was inserted between two attB and attP elements from the bacteriophage lambda, and was oriented inversely to the gene that was to be expressed. After introducing the Int protein, the promoter would automatically rotate to the $\mathrm{ON}$ orientation, which allowed for the expression of the cloned gene. The promoter sequence inversion method was described as molecular acrobatics. Dr. Michał Bereta later adapted this system to control the expression of genes in the more complex cells of humans and other mammals.

Podhajska A.J., Hasan N., Szybalski W., Control of cloned-gene expression by promoter inversion in vivo: construction of the att-p-nutL-att-N module. Gene, 1985, Vol. 40, pp. 163-168.

Hasan N., Szybalski W., Control of cloned gene expression by promoter inversion in vivo: construction of improved vectors with a multiple cloning site and the $\mathrm{p}_{\mathrm{tac}}$ promoter. Gene, 1987, Vol. 56, pp. 145-151.

(2) Even better results were achieved by inverting the gene relative to the stable promoter. In the OFF orientation, only antisense mRNA was synthesized, while switching the gene to the ON orientation, by adding the Int protein, resulted in increased expression of the cloned gene.

Hasan N., Szybalski W., Control of cloned gene expression by its inversion in vivo: switch from anti-sense to sense mRNA. Molecular Genetics of Bacteria and Phages. Cold Spring Harbor 1990.

Sektas M., Szybalski W., Tightly controlled two-stage expression vectors employing the Flp/FRT-mediated inversion of cloned genes. Molecular Biotechnology, 1998, Vol. 9, pp. 17-24.

Hasan N., Koob M., Szybalski W., Escherichia coli genome targeting, I. Cre-lox-mediated in vitro generation of ori plasmids and their in vivo chromosomal integration and retrieval. Gene, 1994, Vol. 150, pp. 51-56.

(3) Using this element and other reversible elements, Professor Szybalski constructed many regulatory systems that act as models of various biological functions; these systems are also useful in gene therapy.

Szybalski W., Construction of novel regulatory circuits. 14th International Congress of Biochemistry, Prague, Czechoslovakia, July 10-15, 1988. Abstracts, Vol. TU: S13-4 (July 12, 1988), Videopress IOJ 16200 Prague 6, 22.

\section{INTEGRATION HOST FACTOR (IHF) (1988-1995)}

Important results were obtained from research on the Integration Host Factor (IHF). This bacterial protein binds to DNA in many places and controls lambda phage transcription negatively or positively.

(1) It was proved that the IHF protein inhibits the transcription of the b2 region in phage lambda. This helped to solve a mystery that could not be explained for many years. Namely, why was it almost impossible to indicate transcription from the b2 region of the phage lambda in vivo, whereas in in vitro experiments (using RNA polymerase), up to $50 \%$ of the transcription origi- nated from this region. Furthermore, IHF partially inhibits the transcription of the phage lambda $\mathrm{pR}$ ' promoter.

Kur J., Hasan N., Szybalski W., Repression of transcription from the b2-att region of the coliphage $\lambda$ by the integration host factor. Virology, 1989, Vol. 168, pp. 236-244.

Kur J., Hasan N., Szybalski W., Integration host factor (IHF) binds to many sites in the A+T-rich b2 region of phage $\lambda$ DNA. Gene, 1992, Vol. 111, pp. 1-9.

(2) The IHF protein has been used to convert restriction enzymes into rare DNA cutters.

Kur J., Koob M., Burkiewicz A., Szybalski W., A novel method for converting common restriction enzymes into rare cutters: integration host factor-mediated Achilles' cleavage (IHF-AC). Gene, 1992, Vol. 110, pp. 1-7.

19.

\section{PROTECTION BY DOMINANT-NEGATIVE MUTANTS}

(1979-1991)

In 1979, Professor Szybalski introduced a novel method for protecting against viral infections using the predominantly negative viral mutations in bacteria, plants, and other organisms. This method was developed as a result of experiments aimed at selecting viral mutants that, by producing a mutant protein, could protect cells against infections caused by the unmutated forms of the same viruses. This concept provided the basis for developing methods of protecting plants against pathogenic viruses.

Szybalski W., Protection of plants against viral diseases by cloned viral genes and anti-genes. Gene, 1991, Vol. 107, pp. 177-179.

Szybalski W., Resistance genes: protection from virus infection using dominant-negative mutations in viral genes [in:] Book of Abstracts, Vol. 1, Washington 1994, p. 492.

This innovative method was patented.

Szybalski W.T., Partially defective foreign gene for conferring immunity on a biological host. U.S. Patent No. 4, 774, 182, Sept. 27, 1988.

20.

\section{NOVEL APPROACHES TO CLONING, AM- PLIFICATION, AND GENOME SEQUENCING} (1998-2010)

Professor Szybalski also has achievements in the mapping and rapid sequencing of large genomes. A number of the methods he developed are now mainly of historical value, because the sequencing of DNA using new generation sequencing (NGS) methods is much more effective. Some of the Professor's achievements include:

(1) Physically mapping genomes using the RecA-AC method (Achilles' heel method using the RecA protein), which permitted measuring distances between sequences (STSs) that are less than $10 \mathrm{Mb}$ (10 million base pairs).

Koob M., Szybalski W., Cleaving yeast and Escherichia coli genomes at a single site. Science, 1990, Vol. 250, pp. 271-273.

Koob M., Burkiewicz A., Kur J., Szybalski W., RecAAC single-site cleavage of plasmids and chromosomes at any predetermined restriction site. Nucleic Acids Research, 1992, Vol. 20, pp. 5831-5836.

Koob M., Szybalski W., Preparing and using agarose microbeads. Methods in Ensymology, 1992, Vol. 216, Part G, pp. 13-20.

Szybalski W., From the double-helix to novel approaches to the sequencing of large genomes. Gene, 1993, Vol. 135, pp. 279-290.

Koob M., Szybalski W., Achilles' cleavage: conferring the specificities of DNA-binding molecules on restric- 
tion endonucleases [in:] Nucleic Acids and Molecular Biology, Vol. 8, ed. F. Eckstein, D.M.J. Lilley, Berlin - Heidelberg 1994, pp. 283-296.

Szybalski W., RecA-mediated Achilles' heel cleavage, Current Opinion in Biotechnology, 1997, Vol. 8, pp. 75-81.

(2) Isolation and amplification of DNA fragments ranging in size from 10 to $100 \mathrm{~kb}(100,000$ base pairs), excised directly from the genome without conventional cloning.

Szybalski W., From the double-helix to novel approaches to the sequencing of large genomes. Gene, 1993, Vol. 135, pp. 279-290.

Pósfai G., Koob M., Hradecna Z., Hasan N., Filutowicz M., Szybalski W., In vivo excision and amplification of large fragments of the Escherichia coli genome. Nucleic Acids Research, 1994, Vol. 22, pp. 2392-2398.

Szybalski W., In vitro and in vivo excision, amplification and rapid SPEL-6 sequencing of genomic fragments [in:] Workshop on Tools for Genome Mapping, ed. B. Dujon, Institut Pasteur, Paris, France, 16 to 18 January 1994, European Commission, EUR 15751 EN, Office for Official Publications of the European Communities, L-2985, Luxemburg 1994, pp. 8-9.

Wild J., Hradecna Z., Pósfai G., Szybalski W., A broad-host-range in vivo pop-out and amplification system for generating large quantities of 50 - to $100-\mathrm{kb}$ genomic fragments for direct DNA sequencing. Gene, 1996, Vol. 179, pp. 181-188.

Szybalski W., Pósfai G., Sektas M., Wild J., In vivo excision of large fragments from bacterial genomes and their amplification: bypassing conventional cloning and subcloning. Genomic Science Series: Small Genomes: Sequencing, Functional Characterization and Comparative Genomics. Hyatt Regency, Hilton Head, January 25-28, 1997, Microbial \& Comp. Genomics 1, p. 385.

Wild J., Sektas M., Hradecna Z., Szybalski W., Towards construction of a prototype library of strains for in vivo excision and amplification of genomic fragments. Genomic Science Series: Small Genomes: Sequencing, Functional Characterization and Comparative Genomics. Hyatt Regency, Hilton Head, January 25-28, 1997, Microbial \& Comp. Genomics 1, p. 387.

Hradecna Z., Wild J., Szybalski W., Conditionally amplifiable inserts in $\mathrm{pBAC}$ vectors. Microbial and Comparative Genomics, 1998, Vol. 3, p. 58.

Yoon Y.G., Pósfai G., Szybalski W., Kim S.C., Cre/ loxP-mediated in vivo excision of large segments from yeast genome and their amplification based on the 2-mm plasmid-derived system. Gene, 1998, Vol. 223, pp. 67-76.

Wild J., Sektas M., Hradecna Z., Szybalski W., Targeting and retrofitting pre-existing libraries of transposon insertions with FRT and oriV elements for in vivo generation of large quantities of any genomic fragment. Gene, 1998, Vol. 223, pp. 55-66.

(3) Sequencing of large genome fragments, from 10 to $100 \mathrm{kB}(100,000$ base pairs) using the primer walking method. This method was much more efficient at the time than sequencing random genome fragments, because it reduced the number of sequenced fragments and shortened the total sequencing time of the studied genome.

Szybalski W., Proposal for sequencing DNA using ligation of hexamers to generate sequential elongation primers (SPEL-6). Gene, 1990, Vol. 90, pp. 177-178.

Szybalski W., Automated sequencing of large genomes without conventional cloning. [13th International Conference on Biochemical Analysis, Munich (FRG), May 5-8, 1992. Symposium 1: Analysis of the human genome: implications for the diagnosis and management of genetic disease]. Fresenius Journal of Analytical Chemistry, 1992, Vol. 343, p. 4.

Szybalski W., From the double-helix to novel approaches to the sequencing of large genomes. Gene, 1993, Vol. 135, pp. 279-290.

Kaczorowski Vol., Szybalski W., Assembly of 18-nucleotide primers by ligation of three hexamers: sequencing of large genomes by primer walking. Analytical Biochemistry, 1994, Vol. 221, pp. 127-135.

Kaczorowski Vol., Szybalski W., Cooperativity of hexamer ligation. Gene, 1996, Vol. 179, pp. 189-193.

Kaczorowski Vol., Szybalski W., Automated fourcolor DNA sequencing using primers assembled by hexamer ligation. Gene, 1996, Vol. 179, pp. 195-198.

Kaczorowski Vol., Szybalski W., DNA sequencing by SPEL-6 hexamer ligation and primer walking. Gene, 1998, Vol. 223, pp. 83-91.

Kaczorowski Vol., Sektas M., Szybalski W., Rapid preparation of denatured double-stranded DNA templates for sequencing. Molecular Biotechnology, 1999, Vol. 11, pp. 199-200.

Kaczorowski Vol., Szybalski W., Nowe podejście do sekwencjonowania DNA oparte na wykorzystaniu starterów uzyskanych przez ligację sześcionukleotydowych oligomerów [A new approach to DNA sequencing based on using primers obtained by the ligation of hexanucleotide oligomers]. Biotechnologia 2000, Vol. 3, pp. 151-163.

(4) Artificial bacterial chromosome (BAC) vectors and other auxiliary methods applicable in genetic engineering.

Hasan N., Koob M., Szybalski W., Escherichia coli genome targeting, I. Cre-lox-mediated in vitro generation of ori plasmids and their in vivo chromosomal integration and retrieval. Gene, 1994, Vol. 150, pp. 51-56.

Sektas M., Gregorowicz M., Szybalski W., Transient conversion to $\mathrm{RecA}^{+}$phenotype to transduction in any Escherichia coli recA- strains. BioTechniques, 1999, Vol. 27, pp. 911-914.

Palmeros B., Wild J., Szybalski W., Le Borgne S., Hernández-Chávez G., Gosset G., Valle F., Bolivar F., A family of removable cassettes designed to obtain antibiotic-resistance-free genomic modifications of Escherichia coli and other bacteria. Gene, 2000, Vol. 247, pp. 255-264.

(5) Conditionally amplifiable BAC vectors.

Hradecna Z., Wild J., Szybalski W., Conditionally amplifiable inserts in pBAC vectors. Microbial and Comparative Genomics, 1998, Vol. 3, p. 58.

Szybalski W., Conditionally amplifiable BAC vector. US Patent No. 5,874,259.

Szybalski W., Wild J., Hradecna Z., Conditionally amplifiable BAC vector. US Patent No. 5,874,259 (revised).

Wild J., Hradecna Z., Szybalski W., Conditionally amplifiable BACs: switching from single-copy to high-copy vectors and genomic clones. Genome Research, 2002, Vol. 12, pp. $1434-1444$.

Szybalski W., Wild J., Hradecna Z., Method for converting single-copy BAC vectors to conditional highcopy PBAC/ORIHC vectors. US Patent and Trademark Office. U.S. Patent Application Publication, Pub. No.: US-2003/0049665 A1, Pub. Date: March 13, 2003, pp. $1-12$.

Wild J., Szybalski W., Copy-control pBAC/oriV vectors for genomic cloning [in:] Recombinant Gene Expression. Reviews and Protocols, ed. P. Balbás, A. Lorence, Totowa: Humana Press 2004, pp. 145-154.

Wild J., Hradecna Z., Szybalski W., Selection for recombinant clones based on the PvuII R-M system. The 2005 Molecular Genetics of Bacteria \& Phages Meeting. August 2-7, University of Wisconsin-Madison 2005, p. 161. 
Wild J., Hradecna Z., Gromek K., Frisch D., Blattner F.R., Szybalski W., Amplifiable BAC8 vector-host system with two cloning modes for preparing genomic libraries. The 2005 Molecular Genetics of Bacteria \& Phages Meeting, August 2-7, University of Wisconsin-Madison 2005, p. 162 .

Wild J., Szybalski W., Lucigen electrocompetent cells are efficiently transformed with BAC clones carrying large DNA inserts. eLucidations, 2005, Vol. 5, pp. 1-2, https://pdfs.semanticscholar.org/dec4/c260d95f107913b87e61bdeff29a52201d1c.pdf [date accessed: 30.01.2018].

(6) Tightly controlled expression vectors (amplified $\mathrm{BAC}$ and other vectors).

Sektas M., Szybalski W., Tightly controlled two-stage expression vectors employing the Flp/FRT-mediated inversion of cloned genes. Molecular Biotechnology, 1998, Vol. 9, pp. 17-24.

Sektas M., Hasan N., Szybalski W., Expression plasmid with very tight two-step control; Int/att-mediated gene inversion with respect to the stationary promoter. Gene, 2001, Vol. 267, pp. 213-220.

Wild J., Hradecna Z., Szybalski W., Single-copy/highcopy (SC/HC) pBAC/oriV novel vectors for genomics and gene expression. Plasmid, 2001, Vol. 45, pp. 142-143.

Szybalski W., Wild J., Hradecna Z., Expression vector with dual control of replication and transcription. US Patent No. 6,472,177 (2002).

Wild J., Hradecna Z., Szybalski W., Conditionally amplifiable BACs: switching from single-copy to high-copy vectors and genomic clones. Genome Research, 2002, Vol. 12, pp. 1434-1444.

Sektas M., Szybalski W., Novel single-copy pETco$\mathrm{co}^{\mathrm{TM}}$ vector with dual controls for amplification and expression. InNOV Ations, 2002, Vol. 14, pp. 6-8.

Wild J., Hradecna Z., Szybalski W., The copy-control expression vectors (pBAC/oriV/trfA) with the tightly controlled ara and rha promoters. Plasmid Biology, 2002, An International Symposium, Pittsburgh, PA USA. June 22 to June 28 2002, pp. 182-183.

Hradecna Z., Wild J., Szybalski W., A family of dual copy-control expression vectors, pBAC/oriV/trfA, ensuring very low background. Abstracts of Papers Presented at the 2002 Meeting on Molecular Genetics of Bacteria \& Phages, Cold Spring Harbor August 20-25, 2002, p. 41.

Wild J., Szybalski W., Copy-control tightly regulated expression vectors based on $\mathrm{pBAC/oriV}$ [in:] Recombinant Gene Expression. Reviews and Protocols, ed. P. Balbás, A. Lorence, Totowa: Humana Press 2004, pp. 155-167.

(7) Sequencing of repetitive DNA fragments using BAC vectors.

Mendez Lago M., Wild J., Abad J.P., Martin-Gallardo A., Villasante A., Szybalski W., Transposon-based innovative method for sequencing highly repetitive heterochromatic DNA in BAC/oriV clones. 45th Annual Drosophila Research Conference, Sponsored by The Genetic Society of America, Washington, March 24-28, 2004, Abstract 981C, p. 30.

Szybalski W., Genomic maps and novel approaches to sequencing of repetitive versus non-repetitive DNA. Polish Journal of Chemistry, 2004, Vol. 78, pp. 1007-1017.

Mendez Lago M., Wild J., Villasante A., Szybalski W., Use of $\mathrm{pBAC}$ \% oriV clones and transposons for sequencing highly repetitive DNA. Abstracts of Papers Presented at the 2004 Meeting on Molecular Genetics of Bacteria \& Phages, Cold Spring Harbor, August 24-29, 2004, p. 51.

Mendez Lago M., Wild J., Abad J.P., Martin-Gallardo A., Villasante A., Szybalski W., Transposon-based innovative method for sequencing highly repetitive hetero- chromatic DNA in BAC/oriV clones [in:] Abstracts, 30th Steenbock Symposium: Gene Expression, Transposition, Genomics and other Life Sciences, May 20-23, 2004, University of Wisconsin-Madison 2004, p. 32.

Mendez Lago M., Wild J., Villasante A., Szybalski W., $\mathrm{BAC} /$ oriV clones and transposons for sequencing highly repetitive DNA. First Annual Genomic Sciences Training Program Retreat. June 21, 2004. The Pyle Center, University of Wisconsin-Madison 2004, p. 23.

Szybalski W., Mendez Lago M., Wild J., Villasante A., Novel approaches to sequencing repetitive versus nonrepetitive genomes. The 5th Parnas Ukrainian-Polish Conference: Molecular Mechanisms of Cellular Signalling, Kyiv, Ukraine, April 26-29, 2005, The Ukrainian Biochemical Journal 2005, Vol. 77, p. 40.

Szybalski W., Wild J., Villasante A., Mendez Lago M., Transposon-based innovative method for sequencing highly repetitive DNA in $\mathrm{BAC} /$ oriV clones. Patent WARF P04312US (2005).

\section{IN DEFENSE OF DNA}

(1970-2010)

Professor Szybalski had always been an adamant defender of science, including genetic research and research on genetically modified organisms (GMO). He also fought against senseless legislation and political attacks on genetic engineering and synthetic biology. It was from this stance that he gave his reports in the US Congress and other parliaments, including the German Bundestag. He was also invited for a private audience with Pope John Paul II, during which he delivered a report on genetic engineering to the pontiff.

Szybalski W., Dangers of legislative and regulatory approaches concerning the hypothetical risks of the recombinant DNA technique [in:] Genetic Engineering, ed. H.W. Boyer, S. Nicosia, Amsterdam: Elsevier-North Holland Biomedical Press 1978, pp. 253-275.

Szybalski W., Much ado about recombinant DNA regulations [in:] Biomedical Scientists and Public Policy, ed. H.H. Fudenberg, V.L. Melnick, New York: Plenum Press 1978, pp. 97-142.

Szybalski W., Dangers of regulating the recombinant DNA technique. Trends in Biochemical Sciences, 1978, Vol. 3, N243-N247.

Szybalski W., Summary and critique of the new NIH Guidelines for recombinant DNA research. Gene, 1979, Vol. 5, pp. 179-196.

Szybalski W., Recommendations against regulations and legislation of reDNA [in:] Chancen und Gefabren der Genforschung. Protokolle und Materialien zur Anbörung des Bundesministers für Forschung und Technologie in Bonn, 19. bis 21. September 1979, hrsg. von E. Herwig, S. Hübner, Münich: R. Oldenbourg Verlag 1980, pp. 297-300, 361-370.

Szybalski W., Asilomar and five years. Trends in Biochemical Sciences, 1980, Vol. 5, pp. VI-IX.

Szybalski W., Trying to please both devils and angels. Trends in Biochemical Sciences, 1980, Vol. 5, pp. XVIIIXIX.

Szybalski W., Benefits and pitfalls of patent policies in academic research employing genetic engineering techniques [in:] From Genetic Engineering to Biotechnology - The Critical Transition, ed. W.J. Whelan, S. Black, New York: John Wiley \& Sons 1982, pp. 223-231.

Szybalski W., Early warning principle offsets the need for regulation of the recombinant DNA technique. BioEssays, 1985, Vol. 2, pp. 147-148.

Szybalski W., Sifting and winnowing: Its meaning and significance to faculty and to freedom of research [in:] Academic Freedom on Trial. 100 Years of Sifting and Winnow- 
ing at the University of Wisconsin-Madison, ed. W.L. Hansen, Office of Univ. Publ., University of Wisconsin-Madison 1998, pp. 235-237.

Szybalski W., Rewolucja genetyczna na przełomie XX i XXI wieku [The genetic revolution of the late twentieth and early twenty-first centuries]. Kosmos 2000, Vol. 49, pp. 385-393.

22.

\section{HISTORY/GENERAL/OBITUARIES} (1970-2010)

Szybalski W., Maintenance of human-fed live lice in the laboratory and production of Weigl's exanthematic typhus vaccine [in:] Maintenance of Human, Animal, and Plant Pathogen Vectors, ed. K. Maramorosch, F. Mahmood, Enfield: Science Publishers, Inc. 1999, pp. 161-180.

Szybalski W., My road to Øjvind Winge, the father of yeast genetics. Genetics, 2001, Vol. 158, pp. 1-6.

Szybalski W., Recollections of 1939-1949. From Politechnika Lwowska to Politechnika Gdańska. Acta Biochemica Polonica, 2003, Vol. 50, pp. XVII-XXI, http://www. lwow.home.pl/szybalski.htm [date accessed: 30.01.2018].

Szybalski W., The genius of Rudolf Stefan Weigl (1883-1957), a Lvovian microbe hunter and breeder - In Memoriam [in:] International Weigl Conference Microorganisms in Pathogenesis and their Drug Resistance - Programme and Abstracts), ed. R. Stoika et al., Lviv 2003, pp. 10-31, http:// www.lwow.home.pl/Weigl/in-memoriam.html [accessed: 30.01.2018].

Szybalski W., Celebration of life of Rudolf S. Weigl (1883-1957), A Leopolitan conqueror of typhus: 50th Anniversary of his passing [in:] Polish Academy of Sciences. Division II, Biological Sciences, The Committee on Microbiology, 2nd Polish-Ukrainian Weigl Conference. Microbiology in the XXI Century, Warsaw Agricultural University, SGGW, Warsaw 2007, pp. 11-33.

Szybalski W., In memoriam. Alexander (Leszek or Leshek) Kohn (1919-1994). A personal tribute. Gene, 1995, Vol. 160, pp. 3-5.

Szybalski W., In Memoriam. Julius Marmur (19261996). Gene, 1997, Vol. 204, p. 1.

Szybalski W., In Memoriam. Karol Taylor (19281997). Gene, 1998, Vol. 223, pp. 393-394.

Szybalski W., In memoriam: Alfred D. Hershey (1908-1997) [in:] We Can Sleep Later. Alfred D. Hershey and the Origins of Molecular Biology, ed. F.W. Stahl, Cold Spring Harbor: Cold Spring Harbor Laboratory Press 2000, pp. 19-22.

Szybalski W., Goodbye, Jagoda - A year after the passing of Anna Jadwiga Podhajska [in:] Anna J. Podhajska (1938-2006). Pierwsza dama polskiej biotechnologii [Anna J. Podhajska (1938-2006). The first lady of Polish biotechnology]. red. W. Makarewicz, E. Łojkowska, Gdańsk: Wydawnictwo Uniwersytetu Gdańskiego 2010, pp. 306310.
23.

\section{INSTITUTIONS AND JOURNALS FOUNDED BY WACKAW SZYBALSKI}

(1945-2010)

1945-1949: cofounder of the Department of Industrial Fermentation and Biotechnology at the Gdańsk University of Technology.

Szybalski W., Ernest Sym. Ojciec biotechnologii [Ernest Sym. The father of biotechnology] [in:] Pioniersy Politechniki Gdanskiej [Pioneers of the Technical University of Gdańsk], red. Z. Paszota, J. Rachoń, E. Wittbrodt, Gdańsk: Wydawnictwo Politechniki Gdańskiej 2005, pp. 629-634.

1976: Wacław Szybalski founded the international scientific journal Gene (GENE. An International Journal Focusing on Gene Cloning and Gene Structure and Function) published in Amsterdam by Elsevier, one of the world's largest scientific publishing houses. He was its editor-in-chief for twenty years. Every issue of Gene bears and will continue to bear an inscription commemorating the name of the Polish scientist from Lwów: FOUNDED IN 1976 BY WACLAW SZYBALSKI.

1976: Wacław Szybalski established the new department of Molecular Genetics at the McArdle Laboratory at the University of Wisconsin-Madison.

2005-2009: Wacław Szybalski significantly contributed to the funding of the Waclaw Szybalski Annex and the Waclaw Szybalski Reading Room, of the Carnegie Library at Cold Spring Harbor Laboratory, Cold Spring Harbor, New York.

Pollock M., Library Plans. Reading, writing, \& renovations. Lab plans Carnegie library rebirth [funded by W. Szybalski]. Harbor Transcript, 2005, Vol. 25, pp. 10-11. 